\title{
Activin Receptor Type-1B
}

National Cancer Institute

\section{Source}

National Cancer Institute. Activin Receptor Type-1B. NCI Thesaurus. Code C28714.

Activin receptor type-1B (505 aa, $\sim 57 \mathrm{kDa}$ ) is encoded by the human ACVR1B gene. This protein plays a role in protein phosphorylation, signal transduction, cell cycle regulation and apoptosis. 